\title{
EKSPLORASI DISPOSISI MATEMATIS MAHASISWA PENDIDIKAN GURU SEKOLAH DASAR MELALUI MODEL PEMBELAJARAN DNR-BASED INSTRUCTION
}

\author{
Marwia Tamrin Bakar ${ }^{1}$, Karman la Nani' ${ }^{1}$, Darmawati Hadi² \\ 1 Prodi Pendidikan matematika Universitas Khairun, Jl. Bandara Sultan Babullah Kode Pos 53 Ternate, Indonesia \\ 2 Prodi PGSD Universitas Khairun, Jl. Bandara Sultan Babullah Kode Pos 53 Ternate, Indonesia \\ email: tmarwia@gmail.com
}

\begin{abstract}
This study aims to explore the mathematical disposition of elementary school teacher education students through the DNR-Based Instruction models on the basic mathematical concept courses. This exploration was carried out by analyzing a questionnaire that was completed by 55 first-year students at one of the state universities in Ternate City. This analysis was conducted in a descriptive qualitative manner by observing the results of learning observations. The disposition questionnaire is arranged on a Likert scale with four answer choices Very often (SS), often (SR), rarely (JR) and very rare (JR). The results showed that students' self-confidence in completing mathematical assignments was considered sufficient. Students have a tenacious and persistent attitude towards mathematics such as being able to complete math tasks for a long time. Students have high curiosity, for example, studying topics that will be taught by lecturers. But students are not flexible in completing mathematical assignments, because they feel comfortable using familiar methods. The results of this study can be used as input to lecturers so that learning can facilitate the growth and development of a positive attitude towards mathematics
\end{abstract}

Key Words: mathematics Disposition, Basic mathematical Concept

\begin{abstract}
ABSTRAK
Penelitian ini bertujuan untuk mengeksplorasi disposisi matematis mahasiswa pendidikan guru sekolah dasar melalui model pembelajaran DNR-Based Instruction pada matakuliah konsep dasar matematika. Ekspolasi ini dilakukan dengan menganalisis angket yang telah diisi oleh 55 mahasiswa tahun pertama pada salah satu perguruan tinggi negeri yang berada di Kota Ternate. Analisis ini dilakukan secara deskriptif kualitatif dengan memperhatikan hasil observasi pembelajaran. Angket disposisi disusun berdasarkan skala likers dengan empat pilihan jawaban yaitu Sangat sering (SS), sering (SR), jarang (JR) dan sangat jarang (JR). hasil penelitian menunjukkan bahwa sikap percaya diri mahasiswa dalam menyelesaikan tugas matematika dikategorikan cukup. Mahasiswa memiliki sikap ulet dan gigih terhadap matematika berupa mampu menyelesaikan tugas matematika dalam waktu yang lama. Mahasiswa memiliki rasa ingin tahu yang tinggi berupa memplejari topik yang akan diajarkan dosen. Namun mahasiswa tidak fleksibel dalam penyelesaian tugas matematika, karena merasa nyaman menggunakan cara yang sudah dikenal. Hasil penelitian ini dapat dijadikan sebagai inputan kepada dosen agar pembelajarannya dapat memfasilitasi tumbuh kembang sikap positif terhadap matematika
\end{abstract}

Kata Kunci: Disposisi Matematis, Konsep Dasar Matematika

Dikirim : 24 September 2019; Diterima: 27 September 2019; Dipublikasikan : 30 September 2019

Cara sitasi: Bakar, M. T., Nani, K. I., \& Hadi, D. (2019). Eksplorasi disposisi matematis mahasiswa pendidikan guru sekolah dasar melalui model pembelajaran DNR-based instruction. Teorema: Teori dan Riset Matematika, 4(2), 131-138. 
Kompetensi yang akan dihasilkan dan menjadi tujuan dari setiap pembelajaran dalam kurikulum 2013 terdiri dari tiga ranah, yaitu kompetensi sikap, kompetensi pengetahuan dan kompetensi keterampilan. Perguruan tinggi sebagai lembaga pendidikan yang menghasilkan calon guru, handaknya menyiapkan mahasiswa agar memiliki ketiga kompetensi tersebut. Ranah pengetahuan dan keterampilan dapat dilatih dalam proses perkuliahan di kelas demikian juga dengan ranah sikap. Sikap seseorang saat bertindak, merupakan refleksi dari pengetahuan dan keterampilan dia yang diperoleh dari proses pembiasaan (dibudayakan). Dalam pembelajaran, sikap dan atau persepsi mahasiswa juga dapat dibentuk dan dinilai sebagai refleksi dari pengetahuan mereka terhadap konten yang dipelajari. Sikap positif dan penilaian diri mereka terhadap matematika tersebut yang disebut disposisi matematis.

Disposisi matematis adalah kompetensi afektif dan sikap sosial mahasiswa/siswa terkait matematika. Kompetensi ini penting untuk dimiliki karena merupakan dasar dari sikap dan persepsi positif mahasiswa terkait matematika. Penekanan pentingnya sikap dalam proses pembelajaran di tuangkan dalam Permendiknas No. 20 tahun 2016 yang menyatakan bahwa: kompetensi lulusan yang harus dipenuhi atau dicapai oleh suatu satuan pendidikan adalah kompetensi sikap, pengetahuan dan keterampilan (Bakar: 2018). Artinya bahwa aspek sikap, pengetahuan dan keterampilan di kembangkaan secara bersamaan saat proses pembelajaran. Namun diakui bahwa kebanyakan pengajar (dosen maunpun guru) belum mengintegrasikan aktivitas pengetahuan dan keterampilan pada domain sikap dalam proses pembelajaran. Pengintegrasian yang dilakukan saat ini masih pada tahapan perencanaan yang dituangkan dalam rencana pembelajaran dan pada penilaian akhir.

Selain kemampuan kognitif, sikap adalah kemampuan afektif yang harus dikembangkan dalam pembelajaran matematika, karena merupakan faktor yang sangat mempengaruhi perilaku seseorang dalam menghadapi suatu tugas (Zakiah, 2017). Pengembangan aspek sikap dalam matematika sejatinya adalah menumbuh kembangkan disposisi matematis. Hal ini dipandang penting karena disposisi matematis bukan hanya digunakan untuk memecahkan masalah matematis, namun digunakan juga untuk memecahkan masalah dalam kehidupan sehari-hari. Pendefinisian mendalam tentang disposisi matematis telah lama dicetuskan oleh NCTM (1989) bahwa disposisi matematis adalah keterkaitan dan apresiasi terhadap matematika, yaitu suatu kecenderungan untuk berpikir dan bertindak positif terkait matematika. Disposisi mahasiswa terhadap matematika dapat terlihat dari sikap dan tindakan selama perkuliahan dan saat memilih strategi yang digunakan untuk menyelesaiakan tugas matematika. Mahasiswa yang memiliki sikap disposisi matematis yaitu mereka yang percaya diri saat belajar matematika, memiliki keingintahuan yangtinggi dalam mencari alternatif, tekun dan tertantang serta memiliki kecenderungan melakukan refleksi terhadap cara berpikir yang dilakukannya. Sikap mahasiswa yang postif terhadap matematika mempengaruhi hasil belajar mareka dalam matematika. Berdasarkan definisi umum disposisi matematis, NCTM (1989) menjabarkan unsur-unsur disposisi sebagai berikut: (1) percaya diri dalam menggunakan matematika; (2) Fleksibel dalam matematika; (3) Gigih dan ulet dalam melaksanakan tugas matematika; (4) memiliki rasaa ingin tahu dalam matematika; (5) melakukan refleksi atas cara berpikir; (6) menghargaai aplikasi matematika; (7) mengapresiasi peranan matematika. Keseluruhan unsur disposisi matematis tersebut, jika dimiliki oleh seseorang, cenderung akan memandang dunia dari konsep matematika serta memanfaatkan matematika untuk menyelesaikan berbagai persoalan yang dihadapi (NCTM; 2000).

Unsur-unsur disposisi matematis menurut Polking (1998) terdiri dari (1) Kepercayaan bahwa matematika dapat digunakan untuk memecahkan masalah, mengkomunikasikan gagasan dan memberikan alasan; (2) Fleksibilitas dalam menyelidiki gagasan dan berusaha mencari metoda alternative dalam memecahkan masalah; (3) Tekun dalam menyelesaikan matematika; (4) memiliki minat, keingintahuan, dan daya temu dalam pekerjaan matematika; (5) kecenderungan untuk memonitor dan merefleksikan penampilan dan penalaran mereka sendiri; (6) menilai aplikasi matematika ke situasi lain yang timbul dalam matematika dan pengalaman sehari-hari; (7) Penghargaan peran matematika dalam kultur nilai, baik matematika sebagai alat maupun sebagai bahasa. Dengan bahasa yang berbeda Maxwel (2001) menggambarkan disposisi matematis sebagai memiliki kecenderungan terhadap matematika, kepekaan terhadapa matematika, kemampuan, dan kesenangan terhadap matematika. Selanjutnya 
Sumarmo (2014) mendefinsikan disposisi matematis sebagai keinginan, kesadaran dan dedikasi yang kuat pada diri mahasiswa untuk belajar dan melaksanakan berbagai kegiatan matematis.

Penelitian terkait disposisi matematis telah banyak diteliti oleh beberapa peneliti sebelumnya. misalnya penelitian oleh Turan, Kolays dan Ulusoy (2012) yang membandingkan disposisi berpikir kritis mahasiswa fakultas pendidikan di Negara Turki menemukan bahwa disposisi berpikir kritis kedua fakultas tidak berbeda secara signifikan baik ditingkat kelas maupun berdasarkan gender. (Nopriana \& Noto; 2017) tentang disposisi berpikir kritis mengemukakan bahwa mahasiswa yang memiliki disposisi berpikir kritis akan cenderung berpikir kritis ketika menghadapi situasi atau kondisi yang menghadirkan stimulus untuk berpikir kritis. Penelitian tentang disposisi matematis pada mahasiswa calon guru juga dilakukan oleh Cooke (2015) mengungkap bahwa persepsi mahasiswa terhadap numerasi dan bagaimana menggunakan matematika di dunia nyata akan membantu tim dosen untuk mengarahkan pengajaran kearah pencapaian yang dinginkan. Berbeda dengan penelitian-penelitian sebelumnya, penelitian ini akan mengekplorasi disposisi matematis mahasiswa setelah di terapkan model pembelajaran DNR-Based Instruction.

Model pembelajaran DNR-Based Instruction adalah model pembelajaran yang menekankan pada konten matematika yakni materi yang akan diajarkan dan bagaimana materi tersebut diajarkan. Menurut Haler (2010) tujuan pembelajaran matematika adalah membantu siswa/mahasiswa mengkonstruksi cara berpikir (ways of thinking) dan cara memahami (ways of understanding). DNR-Based Instruction models dibangun dari tiga prinsip pembelajaran dalam matematika yaitu Duality (D), Necessity (N) dan Repeated reasoning (R). (Bakar, 2018, 2019). Prinsip dualitas (duality principle) memandang bahwa berpikir (ways of thinking) dan cara memahami (ways of understanding) adalah dua hal yang berbeda namun memiliki hubungan timbal balik. Cara berpikir adalah karakteristik kognitif dari tindakan mental, sedangkan cara memahami adalah semua hasil atau produk dari cara berpikir, seperti aksioma, definisi, teorema, bukti, masalah dan solusi.

Prinsip kebutuhan (necessity principle) menegaskan bahwa mahasiswa memiliki kecenderungan untuk belajar, jika mereka melihat ada kebutuhan dari apa yang ingin kita ajarkan kepada mereka, dan menjadi kebutuhan mahasiswa mau mempelajari apa yang telah diajarkan kebutuhan yang dimaksud disini adalaha kebutuhan intelektual (Haler : 2007, Bakar 2019). Prinsip penalaran berulang (Repeated Reasioning Principle) menegaskan bahwa penalaran berulang merupakan cara yang digunakan untuk menginternalisasi, mengorganisasi dan mempertahankan produk kognitif dari tindakan mental saat belajar matematika (Harel 2008c; Bakar 2018). Dari berbagai penjelasan terkait model pembelajaran DNR-Based Instruction di atas, dianggap dapat memfasilitasi mahasiswa dalam belajar matematika khususnya pada matakuliah Konsep Dasar Matematika, dan akan mengungkap disposisi mahasiswa saat bekerja dalam kelompok dan dalam menyelesaikan tugas yang diberikan.

\section{METODE PENELITIAN}

Penelitian ini menggunakan metode deskriptif kualitatif. Selain peneliti sebagai instrumen utama, penelitian ini juga menggunakan beberapa instrumen untuk memperoleh data pendukung yakni: Angket disposisi matematis, lembar observasi aktivitas mahasiswa dan wawancara terstruktur. Indikator disposisi matematis dalam penelitian ini terdiri dari (1)kepercayaan diri; (2) gigih dan ulet; (3) fleksibel; (4) keingintahuan; dan (5) raflektif dan rasa senang; Angket disposis matematis disusun dengan mengacu pada skala Likers dengan menyediakan empat pilihan skala, yakni Sering sekali (SS); sering (SR); jarang (JR) dan jarang sekali (JS). Selanjutnya angket disposisi matematis diberikan pada 55 mahasiswa yang dibelajarkan menggunakan model pembelajaran DNR-Based Instruction di pertemua ke-tujuh dari 16 kali pertemuan pada mata kuliah Konsep dasar matematika. Hal ini dimaksudkan sebagai bentuk konfirmasi antara pilihan mahasiswa pada angket disposisi dengan hasil observasi langsung peneliti terhadap aktivitas mahasiswa selama pembelajaran dan setelah pengisian angket. Pernyataan pada angket disposisi matematis terdiri dari 14 item pernyataan positif dan 13 item pernyataan negatif. Selanjutnya untuk menganalisis angket skala sikap, skala kualitatif tersebut diubah ke bentuk skala kuantitatif. Pemberian skor pada pernyataan positf dimulai dengan skor 4 untuk (SS), skor 3 untuk (SR), skor 2 untuk 
(JR) dan skor 1 untuk (JS). Sebaliknya untuk pernyataan negatif, skor 1 diberikan untuk (SS), skor 2 untuk (SR), skor 3 untuk (JR) dan skor 4 untuk (JS).

Analisis angket disposisi diawali dengan melakukan tabulasi data teste kedalam bentuk tabel. Tabel penskoran yang digunakan adalah model Likert dalam (Hendriana, Rohaeiti, Sumarmo:2017) sebagaimana dijabarkan pada Tabel 1. Berikut:

Tabel 1. Penskoran Skor Butir Soal Model Likert

\begin{tabular}{lllll}
\hline No & \multicolumn{1}{c}{ Jenis Ukuran } & \multicolumn{3}{c}{ Pilihan Jawaban } \\
\cline { 3 - 5 } & & SS & SR & JR \\
\hline 1 & $\mathrm{f}$ & & & \\
2 & $\mathrm{p}$ & & \\
3 & Kum.P & & \\
4 & Tk.tg.kp & & \\
5 & $\mathrm{Z}$ & & \\
6 & Z+2,115 & & & \\
& Pembulatan & & & \\
\hline
\end{tabular}

Keterangan:

$\mathrm{f}$ adalah frekuensi teste yang memilih jawaban yang bersangkutan

p adalah proporsi

kum. p adalah kumulatif proporsi

Tk.tg.P adalah titik tengah kumulatif proporsi

$Z$ adalah nilai statistic $Z$

Pembulatan ke bilangan bulat terdekat.

\section{HASIL DAN PEMBAHASAN}

Analisi data pencapaian disposisi matematis mahasiswa dilakukan untuk melihat kecenderungan mahasiswa terhadap tugas-tugas matematika yang diberikan, kegigihan, fleksibilitas,keingintahuan, sikap reflektif dan rasa senang. Rincian indikator dan pernyataan positif dan negatif dijabarkan pada Tabel 1 sebagai berikut:

Tabel 1. Rincian Indikator DM dan Pernyataan

\begin{tabular}{clccc}
\hline & \multicolumn{1}{c}{ Indikator } & Pernyataan $(+)$ & Pernyataan $(-)$ & Jumlah \\
\hline A. & Kepercayaan diri & $1,3,5$ & $2,4,6$ & 6 \\
B. & Gigih dan Ulet & $7,8,10$ & $9,11,12$ & 6 \\
C. & Fleksibel & 13,15 & 14,16 & 4 \\
D. & Keingintahuan & $17,20,21$ & $18,19,22$ & 6 \\
E. & Reflektif dan rasa sayang & $23,24,27$ & 25,26 & 5 \\
\hline
\end{tabular}

Berdasarkan Tabel 1, terliihat bahwa Indikator kepercayaan diri dijabarkan menjadi enam pernyataan yang terdiri dari 3 (tiga) pernyataan positif (+) dan 3 (tiga) pernyataan negatif (-); indikator gigih dan ulet memilki tiga pernyataan positif dan tiga pernyataan negatif; indikator Fleksibel memuat dua pernyataan posit dan dua pernyataan negative; indikator keingintahuan mempunyai tiga pernyataan negatif dan tiga pernyataan positif dan indikator reflektif dan rasa sayang terdiri dari tiga pernyataan positif dan dua pernyataan negatif. Selanjutnya dilakukan analisis persentasi DM dari 55 responden yang dibelajar menggunakan model pembelajaran DNR-Based Instruction. Rincian tersebut di sajikan pada Tabel 2 sebagai berikut

Tabel 2. Analisis DM berdasarkan Indikator

\begin{tabular}{cccccc}
\hline & Indikator & SS & SR & JR & JS \\
\hline A. & Kepercayaan diri & & & & \\
& + & 69,09 & 116,36 & 85,45 & 29,09 \\
& - & 74,55 & 127,27 & 76,36 & 21,82 \\
B. Gigih dan Ulet & & & & \\
& + & 32,73 & 78,18 & 78,18 & 10,91 \\
& - & 20 & 41,82 & 87,27 & 50,91 \\
C. Fleksibel & & & & \\
\hline
\end{tabular}




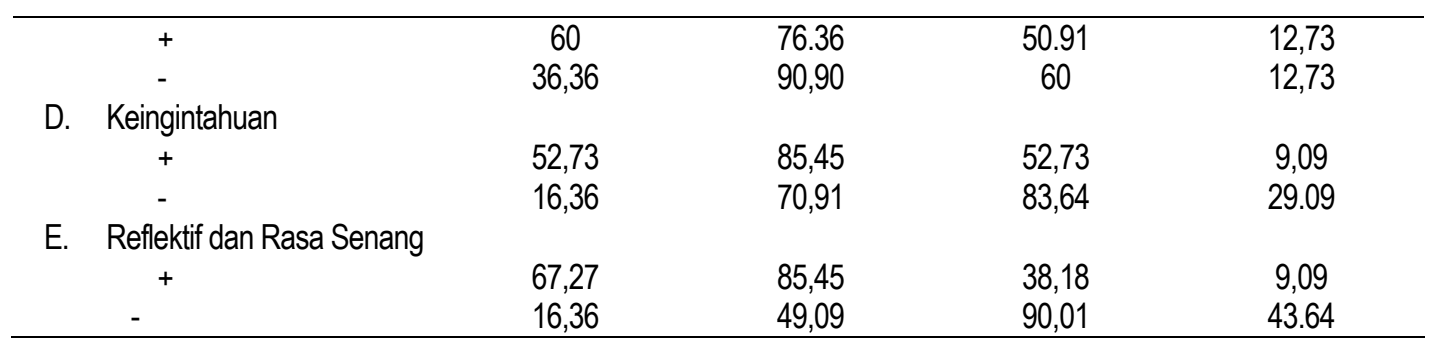

Berdasarkan Tabel 2. Terlihat bahwa indikator rasa percaya diri mahasiswa terhadap matematika (misalnya mampu menyelesaikan tugas matematika yang sulit, memiliki tujuan dalam belajar) sebagai bentuk disposisi matematis, kebanyakan mahasiswa memilih sering $(116,36)$ bersikap positif terhadap matematika. Selanjutnya analisis setiap pernyataan, misalnya merasa yakin menyelesaikan tugas matematika yang sulit, dari 55 mahasiswa, yang memilih "seriing" sebanyak 17 orang (30,91\%), yang memilih "sering sekali" sebanyak 16 orang $(29,09 \%)$ dan memilih "jarang" sebanyak 14 orang $(25,45 \%)$. Pernyataan menetapkan tujuan yang ingin dicapai ketika belajar matematika, kebanyakan mahasiswa memilih "sering" yakni sebanyak 27 orang $(49,09 \%)$, memilih "sering sekali" dan yang memilih 'sering sekali" dan "jarang" masing-masing sebanyak 13 orang $(23,64 \%)$. Sedangkan pada pernyataan "bahwa matematika dapat meningkatkan rasa percaya diri", mahasiswa yang memilih sering dan jarang mempunyai jumlah yang sama yaitu masing-masing sebanyak 20 orang $(36,36 \%)$. Respon ini menunjukkan bahwa masih terdapat sejumlah mahasiswa yang belum merasa yakin dan percaya diri mampu menyelesaikan tugas matematika. Hal ini dikarenakan sebahagian mahasiswa PGSD menghindari matakuliah yang berhubungan dengan matematika. Sedangkan pada pernyataan negatif pada indikator kepercayaan diri, misalnya( cemas ketika mengerjakan tugas, belajar matematika tanpa target, dan meminta bantuan jika sulit) kebanyakan mahasiswa juga memilih sering $(127,27)$. Pernyataan "merasa cemas ketika mengerjakan tugas matematika yang sulit" kebanyakan mahasiswa yaitu sebanyak 27 orang $(49,09 \%)$ yang memilih "sering" dan 11 orang (20\%) yang memilih sering sekali. Pilihan ini menunjukkan bahwa sebagian besar atau sebanyak 38 orang mahasiswa $(69,09 \%)$ mahasiswa PGSD yang merasa cemas ketika menyelesaikan tugas matematika, dan sisanya yaitu sebanyak 17 orang yang tidak memiliki kecemasan saat menyelesaikan tugas matematika yang sulit. Selanjutnya, pernyataan "merasa nyaman belajar matematika tanpa target", sebanyak 21 orang $(38,18 \%)$ mahasiswa memilih "jarang", Artinya bahwa ada mahasiswa $(38,18 \%)$ yang memiliki target saat belajar matematika. selanjutnya terdapat 19 orang mahasiswa $(34,54 \%)$ yang memilih "sering" dan 13 orang $(23,63 \%)$ mahasiswa yang memilih "sering sekali". Jika membandingkan kecenderungan data, maka pada pada indikator kepercayaan diri kebanyakan mahasiswa "sering" merasa tidak percaya diri ketika menyelesaikan tugas matematika.

Pernyataan positif pada indikator memiliki sikap gigih dan ulet misalnya mampu bertahan mengerjakan tugas matematika dalam waktu yang lama, dan tertantang mengerjakan tugas hingga tuntas, kebanyakan mahasiswa menjawab "sering" dan "jarang" dengan kekecnderungan data yang sama (78.18), Hal ini menunjukkan bahwa mahasiswa merespon secara berbeda dengan pernyataan tersebut. saat ditelusuri diperoleh bahwa sebanyak 33 orang mahasiswa dari 55 orang responden atau $60 \%$ mahasiswa menyatakan mampu bertahan mengerjakan tugas matematika dalam waktu yang lama. Kemudian sikap selalu mempelajari terlebih dahulu materi yang akan diajarkan dosen, sebanyak 26 orang mahasiswa dari 55 orang responden atau sebanyak 47\% mahasiswa menjawab "jarang". Karenanya dapat dikatakan bahwa walaupun kebanyakan mahasiswa jarang mempelajari terlebih dahulu materi yang akan diajarkan dosen, namun mahasiswa juga mempunyai sikap mampu bertahan mengerjakan tugas dalam waktu yang lama. sedangkan sikap negatif pada indikator gigih dan ulet misalnya mudah menyerah, merasa minder dan cepat bosan, secara kumulatif mahasiswa memilih jarang $(87,27)$. Sebanyak 28 orang mahasiswa dari 55 orang responden atau 50,91\% mahasiswa menjawab jarang untuk pernyataan mudah menyerah dalam menyelesaikan soal yang kompleks. Sedangkan untuk sikap cepat bosan mempelajari topic matematika tertentu, terdapat 26 orang $(47,27 \%)$ mahasiswa yang memilih 
"jarang" melakukan itu, artinya sebagian msahasiswa suka dengan matematika. walau demikian terdapat 16 orang $(29,09 \%)$ mahasiswa yang merasa "sering" bosan dengan topik-topik matematika tertentu. Sedangkan untuk pernyataan merasa minder saat belajar bersama teman yang pintar, dari 55 orang responden, terdapat 22 orang (40\%) mahasiswa yang memilih "jarang" dan 18 orang (32,72\%) mahasiswa memilih "jarang sekali" merasa minder saat belajar bersama teman yang pintar.

Selanjtnya pada indikator fleksibel, sebanyak 24 orang $(43,64 \%)$ mahasiswa yang menyatakan "sangat sering" dan 22 orang (40\%) mahasiswa yang menyatakan "sering" mempertimbangkan berbagai kemungkinan sebelum mengambil keputusan. Artinya bahwa mahasiswa sebanyak 46 orang (83, 63\%) dari 55 orang mahasiswa yang memiliki kecenderungan sikap selalu mempertimbangkan berbagai kemungkinan sebelum mengambil tindakan. Sedangkan untuk mencari alternatif strategi lain untuk solusi yang sudah dihasilkan, sebanyak 20 orang $(36,36 \%)$ mahasiswa yang menyatakan "sering" dan 22 orang $(40 \%)$ mahasiswa menyatakan "jarang". Data ini terungkap bahwa sebagian mahasiswa sudah merasa cukup dengan solusi yang didapat, dan tidak ingin mencari alternatif yang lain. namun demikian, masih ada diantara mereka yakni sebanyak 29 orang (58\%) mahasiswa yang memiliki kecenderungan untuk mencari alternatiif strategi lain dalam menyelesaikan tugas. Kemudian untuk sikap merasa aman menerapkan strategi yang sudah dikenal, sebanyak 29 orang mahasiswa (52,73\%) memilih "sering". Pilihan ini menggambarkan bahwa kebanyakan mahasiswa PGSD ketika menyelesaikan masalah matematika hanya menggunakan cara penyelesaian yang sudah sering digunakan dan tidak berusaha mencari cara atau pendekatan lain untuk digunakan. Namun demikian masih ada sejumlah mahasiswa yaitu sebanyak 11 orang (20\%) mahasiswa yang memilih "jarang". Sedangkan untuk sikap menyelesaikan soal dengan satu cara, sebanyak 22 mahasiswa (40\%) yang menyatakan "jarang" dan 21 mahasiswa $(38,18 \%)$ yang menyatakan "sering". Berdasarkan kecenderungan data ini terlihat bahwa kebanyakan mahasiswa PGSD tidak fleksibel ketika menyelesaikan tugas matematika yang diberikan.

Indikator keingintahuan, misalnya sikap mempelajari topik matematika dari berbagai sumber, terdapat 22 mahasiswa (40\%) yang menyatakan "sering", 17 orang (30,91\%) yang menyatakan "jarang"; sedangkan sikap berusaha menemukan solusi baru dari masalah yang ada, terdapat 21 mahasiswa $(38,18 \%)$ yang menjawab "sering" dan "jarang", sementara sikap ingin mengetahui kesalahan matematika yang dikerjakan, sebanyak 26 mahasiswa (47,27\%) yang menyatakan "sering "dan 19 mahasiswa $(34,54 \%)$ yang memilih "sering sekali". Selanjutnya untuk pernyataan mempelajari matematika dari berbagai sumber sebagai pemborosan, terdapat 22 orang (40\%) mahasiswa yang menyatakan "jarang" dan 17 orang $(30,91 \%)$ mahasiswa yang menyatakan "jarang sekali". Sementara untuk sikap malas mencoba alternative pemecahan yang baru, terdapat 24 orang $(43,64 \%)$ mahasiswa yang menyatakan "jarang" dan 12 orang $(21,82 \%)$ mahasiswa yang menjawab "jarang sekali".

Indikator reflekstif dan rasa senang, misalnya sikap bertanya pada diri sendiri terkait tugas yang telah dikerjakan terdapat 27 orang $(49,09)$ mahasiswa yang menjawab "sering" dan 22 orsng $(40 \%)$ yang menjawab "sering sekali". Selanjutnya sikap berusaha menyisihkan waktu untuk belajar matematika, terdapat 25 orang $(45,45 \%)$ mahasiswa yang menyatakan "sering", 18 orang $(32.72 \%)$ mahasiswa yang menjawab "jarang" dan 10 orang (18,18\%) yang menjawab "sering sekali". Sedangkan sikap senang bekerja dalam kelompok kecil, sebanyak 27 orang (49.09\%) mahasiswa yang menjawab "sering sekali" dan 22 orang (40\%) mahasiswa yang menjawab "sering". Selanjutnya untuk sikap negative, misalnya tidak memikirkan bagaimana seharusnya belajar matematika yang baik, terdapat 23 orang mahasiswa $(41,82 \%)$ yang menyatakan "jarang" dan 17 orang $(30,91 \%)$ yang menyatakan "sering". Sedangkaan sikap jenuh belajar matematika, terdapat 27 mahasiswa $(49,09 \%)$ yang menyatakan "jarang dan 13 orang $(23,63 \%)$ yang menyatakan "jarang sekali".

Berdasarkan temuan terungkap bahwa pada indikator rasa percaya diri, kebanyakan mahasiswa "sering" merasa tidak percaya diri saat belajar dan berpikir terkait matematika. hal ini disebabkan karena kebanyakan mahasiswa PGSD kurang berminat terhadap matematika. dan memilih pendidikan PGSD karena ingin menghindari matematika. Temuan penelitian ini memberi gambaran kepada kita bahwa penelitian terkait disposisi matematis memiliki kajian dan analisis yang komprehensif. Penelitian ini 
mencoba mengeksplorasi secara lebih mendalam terkait alasan pada setiap pilihan skala yang dilakukan oleh mahasiswa.

\section{KESIMPULAN}

Kesimpulan dari penelitian adalah:

1. sikap percaya diri mahaiswa terkait kemampuan menyelesaikan tugas matematika dikategorikan cukup,

2. Kebanyakan mahasiswa telah berusaha menetapkan tujuan yang ingin dicapai dalam pembelajaran matematika. mahasiswa memiliki sikap mampu bertahan menyelesaikan tugas dalam waktu yang lama,

3. Sebahagian mahasiswa merasa bahwa matematika dapat meningkatkan rasa kepercayaan diri

4. Mahasiswa memiliki sikap gigih dan ulet terhadap matematika, berupa: mampu bertahan mengerjakan tugas dalam waktu lama, dan tertantang untuk menyelesaikan hingga tuntas tugas matematika

5. Mahasiswa memiliki perilaku selalu mempertimbangkanberbagai kemungkinan sebelum mengambil keputusan.

6. Mahasiswa memiliki keingintahuan berupa mempelajari topik, dan ingin menemukan solusi baru

7. Mahasiswa memiliki refleksi terhadap pekerjaan yang dilakukan dan senang belajar matematika dalam kelompok.

\section{REKOMENDASI}

Berdasarkan hasil termua penelitian, direkomendasi kepada:

1. Dosen pengampu matakuliah untuk memperhatikan aspek sikap dalam proses pembelajan khususnya disposisi matematis

2. Perkuliahan di kelas sebaiknya diarahkan pada menumbuhkan perilaku kreatif dan kritis

3. Kepada peneliti yang lain, semoga dapat melanjutkan penelitian disposisi ini

\section{UCAPAN TERIMAKASIH}

Terima kasih kami haturkan kepada pihak-pihak yang terlibat dalam penelitian, diantaranya DR. Karman Lanani M.Si, dan Darmawati Hadi M.Pd yang telah bersedia menjadi pengolah data dalam penelitian

\section{DAFTAR PUSTAKA}

Bakar, T.M. (2018). Peningkatan Kemampuan Pemahaman konsep dan Penalaran serta Disposisi matematis mahasiswa Pendidikan Guru Sekolah Dasar melalui Model DNR-Based Instruction. Disertasi Sekolah Pascasarjana Universitas Pendidikan Indonesia (UPI) Bandung. Tidak dipublikasikan

Bakar T.M, Suryadi D, Tonra S.W, Noto S.M. (2018) The association between conceptual understanding and reasoning ability in mathematic: An analysis of DNR-based instruction models. Journal of Physics: Conference Series 1088 (1), 012107

Bakar T.M, Suryadi D, Darhim D. (2019) Learning Obstacles on Linear equations concept in junior high school students: analysis of intellectual need of DNR Based Instructions. Journal of Physic: Conference Series 1157 (3) 032104

Cooke A. (2015). Considering Pre-Service Teacher Disposition towards Mathematics. Mathematics Teacher Education and Development, 17(1), 1-11. 
Harel, G. (2008c). What is mathematics? A Pedagogical answer to a philosophical question. In R. B. Gold \& R. Simons (Eds.), Proof and other dilemmas: Mathematics and philosophy (pp. 265-290). Washington, DC: Mathematical Association of America.

Harel, G \& Koichu B (2010) An Operational Definition of Learning. The Journal of Mathematical Behavior 29, 115-124 Elsevier.

Hendriana H, Rohaeti E, Sumarmo U (2017) Hard skills dan Soft Skills matematika siswa. Bandung: Aditama.

Maxwell K (2001) Positive learning disposition in mathematics. ACE paper Issue 11.

National Council of Teacher of Mathematics. (1989). Curriculum and Evaluation Standar for School Mathematics. Reston, VA NCTM.

National Council of Teacher of Mathematics. (2000) Principles and Standars for School Mathematics. Reston, VA NCTM,

Nopriana, T \& Noto, S. M (2017). Komunikasi Matematis dan Disposisi Berpikir Kritis Mahasiswa Pendidikan Matematika pada Mata Kuliah Matematika Diskrit. Jurnal Teorema, 1(2), 45-54.

Turan H, Kolais H, Ulusoy O.Y (2012). Comparison of the faculty of education students' critical thinking disposition. Procedia 46 (2012) 2020-2024

Sumarmo, U. (2014). Berpikir dan Disposisi Matematik Serta Pembelajarannya. Kumpulan Makalah Jurusan Pendidikan Matematika dan IImu Pengetahuan Alam, Bandung: UPI.

Zakiah, N. E. (2017). Pembelajaran dengan pendekatan kontekstual berbasis gaya kognitif untuk meningkatkan self awareness siswa. Teorema: Teori dan Riset Matematika 2(1), 11-20. http://dx.doi.org/10.25157/teorema.v2i1 